\title{
The Use of Inquiry-Based Learning Strategy in Teaching Writing Skill for the Eighth Grade Students Junior High School
}

\author{
${ }^{1}$ Hidayatul Isra', ${ }^{2}$ Maman Asrobi \\ ${ }^{12}$ Hamzanwadi University, Indonesia \\ Correspondence: Hidayatul Isra', Hamzanwadi University, Indonesia. E-mail: hidayatulisra705@gmail.com \\ Received: Februari 20, 2018 \\ Accepted: Maret 21, $2018 \quad$ Online Published: April 1, 2018 \\ doi: 10.29408/veles.v2i1.606.g429 \\ URL: http://dx.doi.org/10.29408/veles.v2i1.606.g429
}

\begin{abstract}
This present study investigated the use of inquiry-based learning strategy in teaching writing skill for the eighth grade students of MTs. NW Dames in the school year 2016-2017. Research methodology that was used in this study was pre-experimental research and the design was a one group pretest and posttest design. The population was eighth grade students consisted of two classes and took one class as the sample. The sampling technique in this study was cluster random sampling. The data collection was done by administering pre and post-test to the eighth grade students of MTs. NW Dames (21 students). Then to analyze the data, the present researcher used a paired samples t-test by using SPSS 22 for windows. Based on the data analysis, the present researcher found that the mean score of pre-test was 59.14 and post-test was 63.62 , it could be stated that null hypothesis was rejected and the hypothesis was accepted. Inquiry-based learning strategy was significantly effective in teaching writing skill for the eighth grade students of MTs. NW Dames in the school year 2016-2017. Considering the process and the results of this research, the present researcher suggested that English teacher can use inquiry-based learning strategy to teach students.
\end{abstract}

Keywords: inquiry-based learning strategy, writing skill

\section{Introduction}

Learning English is very important. Many people use and learn English for many purposes. According to Broughton (1980, p. 6), "English is a foreign language in the rest of the world". Based on above opinion, in Indonesia, English is as foreign language. English is also called as the target language that has to be taught in schools in today's Indonesian curriculum. Therefore, the students is hoped to learn and communicate in English so that students can practices in their daily activity.

In learning English there are four skills should be mastered by the students especially students in junior high school, that are listening, speaking, reading and writing (BSNP, 2006). 
These four skills are regarded as the serious problem for them. Like three other skills, listening, reading, and writing, speaking is viewed as the significant one. So, the present researcher focuses on writing.

Among the four language skill taught in schools, writing is the most difficult skill to learn. Heaton (1989, p. 135) states that "writing skills are complex and sometimes difficult to teach, requiring not mastery not only of grammatical and rhetorical devices but also conceptual and judgmental elements". It means that, writing needs special skill that includes the ability to express the writer's opinions or thought clearly and efficiently. These abilities can be achieved only if a learner masters some techniques of writing such as how to obtain ideas about what learners will write on, how to express the ideas in a sequence of sentences, how to organize the ideas chronologically and coherently, and how to review and then to revise the composition until the writing is well built (Ratnasari, 2004).

Based on the expert's opinion above, the problem was found in MTs. NW Dames especially in English teaching was the teacher was not creative in finding strategy to reach the objective of teaching and learning. It is found that media is any person, material or event that exploited conditions that enable learners to acquire knowledge and skills. On the other hand, in teaching writing teacher needed various strategies to improve students' interest in classroom, teacher must change their class situation into enjoyable and attractive impressions. Using strategy could help the students to comprehend some kinds of text. Moreover, in teaching writing ability, the teacher should not teach the students to memorize the word then produced only after memorizing it to be able to write, but teacher needed to help them by using a strategy to respond it in written. Considering the fact, the teacher would use the strategy to help the students to comprehend the word in writing.

The use of monotonous strategy also made students feel bored in learning process. One of strategies which was rarely used by the teacher especially in teaching writing was Inquiry BasedLearning. Inquiry Based-Learning could be defined as something or a treatment that was used to attract students' motivation to follow the teaching and learning process. The use of Inquiry Based-Learning was hoped to solve the problem of the students in classroom, especially when they learned about writing. Because of the difficulties of writing, teacher should give more attention to teach writing skill to improve the students' skill in writing. At least, the learner could write simple or basic text. One of the ways of improving the students' attention in writing by using strategy. One kind of useful strategies in teaching process was Inquiry-Based Learning Strategy.

Inquiry-Based Learning is a complex process where students formulate questions, investigate to find answers, build new understandings, meanings and knowledge, and then communicate their learning to others. In classroom where teachers emphasize inquiry learning, students are actively involved in solving authentic (real life) problems within the context of the curriculum and community. These powerful learning experiences engage students deeply. 
Based on the above phenomenon the above present researcher intended to investigate the use of Inquiry Based Learning Strategy in teaching writing ability for the eighth grade students of MTs. NW Dames in the school year 2016-2017.

\section{Method}

The method that was used in this study was a pre-experimental method. According to Sugiyono (2010, p. 73), "experimental method is divided into four, namely true-experimental, pre-experimental, factorial design, and quasi experimental design". In line with this statement, the present researcher used pre-experimental methodology, by using one class as experimental group, that was called one group pre-test and post-test design. This method is not yet a serious experiment because there are still external variables that contribute to the formation of the dependent variable. So the result of experiment which is dependent variable is not solely influenced by independent variable. This occurs because there is no control variable.

\subsection{Participants}

The population of the study was the students of MTs. NW Dames in the odd semester in the school year 2016-2017 which consisted of 2 classes. The total number of the students was 41 students. The present researcher took VIIIA class only 21 students who had problems in writing especially about narrative text and through cluster random sampling technique.

\subsection{Data Collection}

Before the research is carried out, the instrument of the research should be well prepared. In a research, the meaning of instrument is kind of teaching aids that can be used to collect data (Suharsimi, 2006). To collect the data, the present researcher used writing test in the form of a formative test. The type of the test delivered was divided into two categories; pre-test and post test. Pre-test was given to the class investigated before conducting treatment by using inquirybased learning strategy in teaching writing skill. Meanwhile, post-test was given after conducting the treatment in teaching and learning process by using inquiry-based learning strategy.

All the data of the study were collected using the prepared instruments. All the instruments were sequentially presented to the participants of the current study. The first meeting was the pretest, It was done to the students' writing skill with some appropriate topics provided before conducting the treatment, followed by the treatment for one day and finally the post-test within 30 minutes.

\subsection{Data Analysis}

The data of this study were collected and analyzed by using descriptive statistic and inferential analysis. Descriptive analysis was used to know the mean, median, mode, and standard deviation of students' scores in reading test. Inferential analysis was used to know normality and homogeneity previously before the t-test. Normality test was conducted in order to know whether the sample distributed normally or not, while homogeneity test aim at knowing 
The Use of Inquiry-Based Learning Strategy in Teaching Writing Skill

for the Eighth Grade Students Junior High School

whether the data are homogeneous or not. For this purpose, the researcher performed Frequencies using SPSS 22 for windows.

There are two statistics required for testing hypothesis; those are normal distribution test and homogeneity test which are both statistics were analyzed by using SPSS Statistics 22 for windows. First, normality testing was used to know whether or not the data has normal distribution. To know the data was normal or not, the researcher performed One-Sample K-S using SPSS 22 for windows, and the last homogeneity was conducted to know whether the obtained data of the sample was homogenous or not. Homogeneity testing was performed by One-Way ANOVA using SPSS 22 for windows. To know the effectiveness of Inquiry-Based Learning strategy in teaching writing skill, the present researcher used SPSS Statistics 22 for Windows. As the output, the SPSS statistics showed the result of the procedure which indicated that the hypothesis was accepted or rejected.

\section{Results}

The result of the study in this part was to know mean score and standard deviation of the student's test. The result of mean score of pre-test was 40.71. Standard deviation of pre-test was 12.68. While the result of mean score of post-test was 59.28 and the standard deviation of posttest was 12.68 . To be more clearly, the result above could be seen in Table 1 .

Table 1. The Result of Mean score and Standard Deviation

\begin{tabular}{llll}
\hline No & Activity & Mean & Standard Deviation \\
\hline 1 & Pre-test & 59.14 & 3.785 \\
2 & Post-test & 63.62 & 4.248 \\
\hline
\end{tabular}

Based on the result of calculation above, the present researcher found that there was significant effect of inquiry based learning after giving treatment. It could be seen on the result of post-test above. The result of the study in this part was normal distribution and homogeneity. Both of them are calculated by SPSS statistic 22 for windows.

Normality testing was used to know whether or not the data has normal distribution. To know the data was normal or not, the researcher performed One-Sample K-S using SPSS 22 for windows. To be more clearly, the result of normality testing could be seen in Table 2 .

Table 2. The Result of Normal Distribution One Sample Colmogorov-Smirnov Test

\begin{tabular}{llll}
\hline \multirow{2}{*}{ Activity } & $\begin{array}{l}\text { Kolmogrov-smirnov } \\
\text { Statistic }\end{array}$ & df & Sig. \\
\hline Pre-test & 0.134 & 21 & 0,200 \\
Post-test & 0.134 & 21 & 0,200 \\
\hline
\end{tabular}


The Use of Inquiry-Based Learning Strategy in Teaching Writing Skill

for the Eighth Grade Students Junior High School

Homogeneity was conducted to know whether the obtained data of the sample was homogenous or not. To be more clearly, the result of Homogeinity could be seen in Table 3 .

Table 3. The Result of Homogeneity Levene Statistic Test of Homogeneity of Variance

\begin{tabular}{lllll}
\hline & Levene Statistic & df1 & df2 & Sig. \\
\hline Prepost & 0.685 & 1 & 40 & 0.413 \\
\hline
\end{tabular}

According to the data above, the value of levene's statistic was 0.685 at $p=0.413$, which is greater than 0.05 . In other words, the variance of the data was homogeneous. To know the hypothesis testing, the present researcher used paired Sample T-Test by using SPSS 17 for windows to calculate the data. The hypothesis in this study was inquiry based learning significantly effective in teaching writing skill for the eighth grade students of MTs. NW Dames in the school year 2016-2017. The result can be seen on the Table 4.

Table 4. The Result of Testing Hypothesis Paired sample T-Test

t df Sig 2 tailed

\begin{tabular}{llllll}
\hline Pair 1 & Pre-test & Post-test & 6,669 & 20 & 0.000
\end{tabular}

Based on the result of testing hypothesis above, the conclusion of this analysis by using paired sample t-test, $=6,669, \mathrm{df}=20, \mathrm{p}=0.00$. It showed that the value of the significance 2 tailed was lower than 0.05. It meant that the alternative hypothesis (Ha) was accepted and the null hypothesis (Ho) was rejected. Based on the result of calculation above, the present researcher states that inquiry based learning was effective in teaching writing skill for the eighth grade students of MTs. NW Dames in the school year 2016-2017.

The detail data regarding the achievement of the students in pre-test showed that 1 students (4.8\%) categorized into "Good", and 20 students $(95.2 \%)$ was sufficient. While the detail data regarding the achievement of the students in post-test was as follows: 7 students (33.3\%) categorized into "good" and 14 students $(66.7 \%)$ categorized into "sufficient". Therefore, it can be concluded that there are 7 students (33.3\%) had achieved the standard score of succes (65). To be more clearly, Students' level ability couin Pre-test and Post-test could be seen in table 5 and Table 6.

Table 5. Students' Level Ability in Pre-Test

\begin{tabular}{lllll}
\hline No & Name & Total Score & Category & Percentage \\
\hline 1 & HL & 69 & Good & $4.8 \%$ \\
2 & AL & 61 & Sufficient & $95.2 \%$
\end{tabular}


The Use of Inquiry-Based Learning Strategy in Teaching Writing Skill for the Eighth Grade Students Junior High School

\begin{tabular}{llll}
3 & AT & 63 & Sufficient \\
4 & DW & 52 & Sufficient \\
5 & EA & 61 & Sufficient \\
6 & ED & 59 & Sufficient \\
7 & FTR & 59 & Sufficient \\
8 & FSI & 57 & Sufficient \\
9 & HAS & 57 & Sufficient \\
10 & H & 53 & Sufficient \\
11 & HJ & 56 & Sufficient \\
12 & SJ & 59 & Sufficient \\
13 & KT & 64 & Sufficient \\
14 & MIR & 60 & Sufficient \\
15 & NKK & 60 & Sufficient \\
16 & RA & 55 & Sufficient \\
17 & RP & 58 & Sufficient \\
18 & SZ & 63 & Sufficient \\
19 & S & 58 & Sufficient \\
20 & TK & 59 & Sufficient \\
21 & AT & 59 & Sufficient \\
\hline
\end{tabular}

Table 6. Students' Level Ability in Post-Test

\begin{tabular}{lllll}
\hline No & Name & Total Score & Category & Percentage \\
\hline 1 & HL & 70 & Good & \\
2 & AL & 68 & Good & \\
3 & AT & 65 & Good & $33.3 \%$ \\
4 & DW & 65 & Good & \\
5 & EA & 67 & Good & \\
6 & ED & 72 & Good & \\
7 & FTR & 72 & Good & \\
8 & FSI & 64 & Sufficient & \\
9 & HAS & 59 & Sufficient & \\
10 & H & 61 & Sufficient & \\
11 & HJ & 60 & Sufficient & \\
12 & SJ & 64 & Sufficient & \\
13 & KT & 62 & Sufficient & \\
14 & MIR & 60 & Sufficient & \\
15 & NKK & 61 & Sufficient & \\
16 & RA & 62 & Sufficient
\end{tabular}


The Use of Inquiry-Based Learning Strategy in Teaching Writing Skill

for the Eighth Grade Students Junior High School

$\begin{array}{llll}17 & \text { RP } & 64 & \text { Sufficient } \\ 18 & \text { SZ } & 57 & \text { Sufficient } \\ 19 & \text { S } & 63 & \text { Sufficient } \\ 20 & \text { TK } & 62 & \text { Sufficient } \\ 21 & \text { AT } & 58 & \text { Sufficient }\end{array}$

\section{Discussion}

Inquiry-based learning strategy is effective to be used in teaching writing ability. It cannot be denied that teaching strategy which is used by the teacher in the class gives a big influence to the success of the teaching and learning process. In this case, inquiry based-learning strategy automatically emphasizes the development of cognitive, affective, and psychomotor a balanced way, so that learning through this strategy is considered more meaningful. During treatment process, applying inquiry-based learning strategy made students be anxious, so that students would try to seek and find the answer themselves.

In addition, the entire activity of the student is directed to seek and find the answers themselves from something that is questionable, which is expected to foster self-confidence (self belief). Thus, the inquiry learning puts the teacher is not the only source of learning, but more as a facilitator and motivator of student learning. Learning activities are usually done through a process of questions and answers between teacher and student. Because of the ability of teachers to use questioning is a major requirement in the conduct of inquiry. Related to this, Sanjaya (2006) states that inquiry learning strategy is a series of learning activities that emphasize the process of thinking critically and analytically to seek and find their own answer to the problem in question. In other word, the thought process is usually done through a question and answer between teachers and students.

Based on the result of this research, the mean score of pre-test was 59.14 while post-test was 63.62. So, it can be concluded that inquiry-based learning strategy was effective in teaching students' writing skill for the eighth grade students of MTs. NW Dames in the school year 20162017.

\section{Conclusion}

Based on the research result and discussion, it can be concluded that Inquiry-based learning strategy (IBL) is significantly effective in students' writing skill. It is proved that students' writing ability through Inquiry-based learning strategy is higher than before applying the strategy in pre-test. The alternative hypothesis (Ha) which state that the use of Inquiry-based learning strategy in teaching writing skill for the eighth grade students of MTs. NW Dames in the school year 2016-2017 was accepted. 
The Use of Inquiry-Based Learning Strategy in Teaching Writing Skill

for the Eighth Grade Students Junior High School

\section{References}

Alawi, F. F. (2011). Improving students' ability in writing descriptive text using clustering techniqueAn Action Research at eight grade students of MTs. Darul Ma'arif Cipete-Jakarta. Undergraduate thesis. Cihan University, Erbil, Iraq.

Al-Jumaily, Samir. (2014). Improving my students' writing skill: an intensive course for ESL learners by using process-approach to writing with the assistance of computer word processor. 2(1),29-35.

Anderson, M., \& Anderson, K. (1998). Text types in English 3. Australia: MacMillan.

Arikunto, Suharsimi. (2010). Prosedur penelitian: Suatu pendekatan praktik. Jakarta: PT. Rineka Cipta.

Ary,Donald., et al. (2010). Introduction to research in education.Eighth edition. USA, Wadsworth: Cengange Learning.

Broughton, G.,Brumfit, C., Flavell, R., Hill, P., \&Pincas, A. ( 1980).Teaching English as a Foreign Language Second Edition. Canada: Routledge.

Brown, H. D. (2003). Language assesment principle and classroom practice. Second edition. San Francisco, California: Pearson Longman.

BSNP. (2006). Syllabus English in junior high school SMP/MTs. Jakarta: Depdiknas.

Ernaningsih. (2014). The effectiveness of inquiry-based learning in teaching writing ability for the eight graders of SMPN 2 Selong in the school year 2014-2015. Undergraduate thesis. Hamzanwadi University, NTB, Indonesia.

Fitriani. (2016). The effectiveness of think talk write strategy in teaching writing narrative text to the eight graders of MTs. Mu'allimin NW Pancor in the academic year 2015-2016. Undergraduate thesis. Hamzanwadi University, NTB, Indonesia.

Heaton, J. B. (1989). Writing English language test. London and New York:Longman Group. Moedjito. (2016). Basic statistik for reseach in language education. Surakarta: Yuma Pustaka Ratnasari, Nana. (2004). Tehnik menulis efektif. Bandung: Diva Press.

Riyanto. (2009). Mendesain model pembelajaran inovatif - progresif. Jakarta: Kencana.

Sanjaya, Wina. (2006). Strategi pembelajaran berorientasi standar proses pendidikan. Jakarta: Kencana.

Team Study Program of English.(2017). Thesis manual. Lombok Timur, Pancor: STKIP Hamzanwadi 